\title{
Article \\ Oligomerization and Nitration of the Grass Pollen Allergen Phl p 5 by Ozone, Nitrogen Dioxide, and Peroxynitrite: Reaction Products, Kinetics, and Health Effects
}

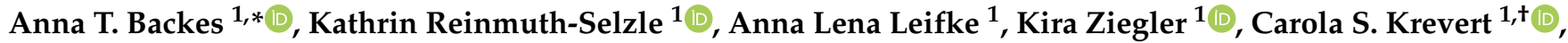 \\ Georg Tscheuschner ${ }^{2}$, Kurt Lucas ${ }^{1} \mathbb{D}$, Michael G. Weller ${ }^{2} \mathbb{D}$, Thomas Berkemeier ${ }^{1}$ (D), Ulrich Pöschl ${ }^{1} \mathbb{D}$ \\ and Janine Fröhlich-Nowoisky ${ }^{1, * \mathbb{D}}$
}

1 Multiphase Chemistry Department, Max Planck Institute for Chemistry, 55128 Mainz, Germany; k.selzle@mpic.de (K.R.-S.); a.leifke@mpic.de (A.L.L.); kira.ziegler@hotmail.com (K.Z.); krevertc@mpip-mainz.mpg.de (C.S.K.); k.lucas@mpic.de (K.L.); t.berkemeier@mpic.de (T.B.); u.poschl@mpic.de (U.P.)

2 Division 1.5 Protein Analysis, Federal Institute for Materials Research and Testing (BAM), 12489 Berlin, Germany; georg.tscheuschner@bam.de (G.T.); michael.weller@bam.de (M.G.W.)

* Correspondence: anna.backes@mpic.de (A.T.B.); j.frohlich@mpic.de (J.F.-N.)

check for

updates

Citation: Backes, A.T.

Reinmuth-Selzle, K.; Leifke, A.L.;

Ziegler, K.; Krevert, C.S.;

Tscheuschner, G.; Lucas, K.; Weller, M.G.; Berkemeier, T.; Pöschl, U.; Fröhlich-Nowoisky, J.

Oligomerization and Nitration of the Grass Pollen Allergen Phl p 5 by

Ozone, Nitrogen Dioxide, and

Peroxynitrite: Reaction Products, Kinetics, and Health Effects. Int. J. Mol. Sci. 2021, 22, 7616. https:// doi.org/10.3390/ijms22147616

Academic Editor: Claudiu T. Supuran

Received: 1 June 2021

Accepted: 13 July 2021

Published: 16 July 2021

Publisher's Note: MDPI stays neutral with regard to jurisdictional claims in published maps and institutional affiliations.

Copyright: (c) 2021 by the authors. Licensee MDPI, Basel, Switzerland. This article is an open access article distributed under the terms and conditions of the Creative Commons Attribution (CC BY) license (https:// creativecommons.org/licenses/by/ $4.0 /)$.
+ Current address: Department of Molecular Spectroscopy, Max Planck Institute for Polymer Research, 55128 Mainz, Germany.

Abstract: The allergenic and inflammatory potential of proteins can be enhanced by chemical modification upon exposure to atmospheric or physiological oxidants. The molecular mechanisms and kinetics of such modifications, however, have not yet been fully resolved. We investigated the oligomerization and nitration of the grass pollen allergen $\mathrm{Phl} p 5$ by ozone $\left(\mathrm{O}_{3}\right)$, nitrogen dioxide $\left(\mathrm{NO}_{2}\right)$, and peroxynitrite $\left(\mathrm{ONOO}^{-}\right)$. Within several hours of exposure to atmospherically relevant concentration levels of $\mathrm{O}_{3}$ and $\mathrm{NO}_{2}$, up to $50 \%$ of Phl 5 were converted into protein oligomers, likely by formation of dityrosine cross-links. Assuming that tyrosine residues are the preferential site of nitration, up to $10 \%$ of the 12 tyrosine residues per protein monomer were nitrated. For the reaction with peroxynitrite, the largest oligomer mass fractions (up to $50 \%$ ) were found for equimolar concentrations of peroxynitrite over tyrosine residues. With excess peroxynitrite, the nitration degrees increased up to $40 \%$ whereas the oligomer mass fractions decreased to $20 \%$. Our results suggest that protein oligomerization and nitration are competing processes, which is consistent with a two-step mechanism involving a reactive oxygen intermediate (ROI), as observed for other proteins. The modified proteins can promote pro-inflammatory cellular signaling that may contribute to chronic inflammation and allergies in response to air pollution.

Keywords: tyrosine; nitrotyrosine; dityrosine; nitration degree; protein dimer; protein oligomer

\section{Introduction}

The prevalence of allergic diseases and asthma is increasing worldwide, and especially the complexity and severity in children and young adults continue to rise, particularly in newly industrialized countries such as China or India [1-5]. The rapid increase in the prevalence, however, cannot be explained by genetic factors alone, and environmental factors must be taken into account [6-9]. Indeed, several studies have suggested that allergic diseases are enhanced by traffic-related air pollution [10-12], and it has been shown that birch and ragweed pollen from urban areas had a higher allergenic potential than pollen from rural areas $[13,14]$. Pollen can rupture upon exposure to anthropogenic air pollutants such as ozone $\left(\mathrm{O}_{3}\right)$ or nitrogen dioxide $\left(\mathrm{NO}_{2}\right)$ or under humid conditions and release cytoplasmic material including allergenic proteins and biogenic adjuvants into the environment [15-18]. The released proteins can attach to larger particles such as soil or road dust or be dissolved in water, where they can interact in an aqueous environment with 
gaseous and particulate air pollutants [19-21]. The results are chemical posttranslational modifications, which can change the protein structure and stability, affect polarity and acidity of binding sites, and therefore alter the immunogenicity of the proteins [22-27].

In the atmosphere, proteins can react with reactive oxygen and nitrogen species (ROS, RNS) such as $\mathrm{O}_{3}$ and $\mathrm{NO}_{2}$, resulting in oxidized, nitrated, and degraded proteins as well as protein oligomers $[19,21,28]$. In addition to chemical modification in the environment, inhaled air pollutants can lead to ROS production, oxidative stress, and inflammation in the human body [29-31]. During these processes, nitrogen oxide radicals (NO) and superoxide anions $\left(\mathrm{O}_{2}^{-}\right)$are formed, which rapidly react to peroxynitrite $\left(\mathrm{ONOO}^{-}\right)$[32]. Similar to the reaction of proteins with $\mathrm{O}_{3}$ and $\mathrm{NO}_{2}$, peroxynitrite can also lead to protein oligomerization and nitration [33-35]. Although several studies were already published investigating the reaction mechanisms and kinetics of chemical protein modification, they do not allow drawing conclusions regarding possible health effects of modified proteins. To investigate real health effects, studies with modified health-related proteins such as allergens or other immunomodulatory proteins are indispensable.

In this study, we investigated the chemical modification of recombinant Phl p 5.0101, simply termed Phl $\mathrm{p} 5$ hereafter, a major allergen of timothy grass pollen (Phleum pratense). Exposure to $\mathrm{Phl} \mathrm{p} 5 \mathrm{can}$ induce rhinitis and bronchial asthma in patients allergic to grass pollen [36]. The native protein function, however, is not yet clear, but it is supposed, that the protein plays a role in pollen germination [37]. The protein is estimated to represent about $6 \%(w / w)$ of the whole pollen extract [38]. The recombinant protein has a molecular weight of $28.6 \mathrm{kDa}$ according to the manufacturer and consists of 287 amino acids including 12 tyrosine residues $(\sim 4 \%)$. The structure of the protein comprises two flexibly connected domains of similar size that include identical secondary structural elements such as four parallel $\alpha$-helices [37].

To mimic air pollution effects, recombinant $\mathrm{Phl} p 5$ was exposed to a mixture of $\mathrm{O}_{3}$ and $\mathrm{NO}_{2}$ in aqueous phase under various atmospherically relevant conditions $\left(\mathrm{O}_{3} / \mathrm{NO}_{2}\right.$ concentrations: $50 \mathrm{ppb} / 50 \mathrm{ppb}, 200 \mathrm{ppb} / 200 \mathrm{ppb}$; exposure time: $0.5-10 \mathrm{~h}$ ). Please note that the experimental design used in this study (small gas bubbles in a large volume of liquid) is only partially comparable to exposure in the atmosphere (small liquid droplets in a large volume of gas). In both systems, however, the rate of protein modification is likely determined by gas solubility and chemical reaction rate. In contrast, under dry conditions or in a (semi-)solid aerosol matrix, slow diffusion may influence reaction kinetics and lead to different oligomerization and nitration degrees [39]. For the investigation of endogenous protein modification during oxidative stress, Phl p 5 was treated with different $\mathrm{ONOO}^{-}$concentrations $(0.04-2 \mathrm{mM})$. Size-exclusion chromatography was used to analyze protein oligomer mass fractions and their tyrosine nitration degrees simultaneously, and the different protein fractions were confirmed by SDS-PAGE. Reversed-phase chromatography was used to determine the total tyrosine nitration degree and estimate the number of nitrotyrosine residues. For selected samples, the results were compared to MALDI-TOFMS measurements. To our knowledge, this is the first time that the recombinant grass pollen allergen Phl $\mathrm{p} 5$ has been modified by ozone and nitrogen dioxide as well as peroxynitrite to mimic exogenous and endogenous protein modifications through direct and indirect air pollution effects.

\section{Results and Discussion}

\subsection{Oligomerization}

Native and modified Phl p 5 samples were analyzed by size-exclusion chromatography (SEC-HPLC) for protein dimers and higher oligomers (for exemplary chromatograms, see Supplementary Materials Figure S1). Native Phl p 5 consists primarily of protein monomers $(>99 \%)$, but also contains a small mass fraction of dimers $(<1 \%)$. For native Phl p 5, higher oligomers $\left(\mathrm{MW}>\mathrm{MW}_{\text {dimer }}\right.$ ) were not detectable in our study.

Figure 1 shows the effect of low (50 ppb/50 ppb) and high (200 ppb/200 ppb) concentrations of $\mathrm{O}_{3} / \mathrm{NO}_{2}$ on the oligomerization of Phl $\mathrm{p} 5$ for different exposure times. Generally, 
the mass fractions of Phlp 5 dimers and higher oligomers increased over the course of exposure time while the mass fraction of monomers decreased. We found up to $18 \pm 2 \%$ dimers at low $\mathrm{O}_{3} / \mathrm{NO}_{2}$ concentrations and up to $21 \pm 3 \%$ at high oxidant concentrations after $10 \mathrm{~h}$ of exposure (Figure 1B). While the final dimer mass fractions were similar, the temporal evolution of the dimer mass fractions deviated for the two exposure levels. At low $\mathrm{O}_{3} / \mathrm{NO}_{2}$ concentrations, the dimer mass fraction increased only slightly at short exposure times, but showed a steeper increase for longer exposure times. In contrast, at high oxidant concentrations, the dimer mass fraction increased rapidly within the first $4 \mathrm{~h}$, but stayed constant at longer exposure times.

A

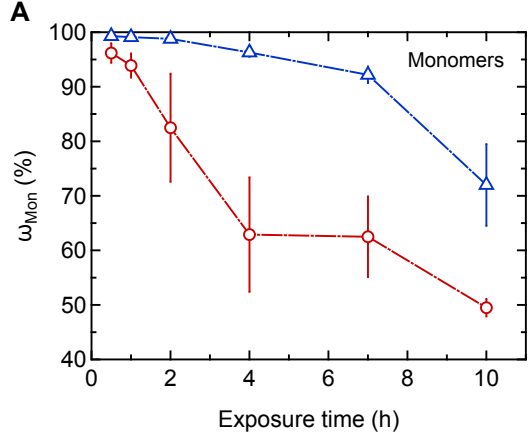

B

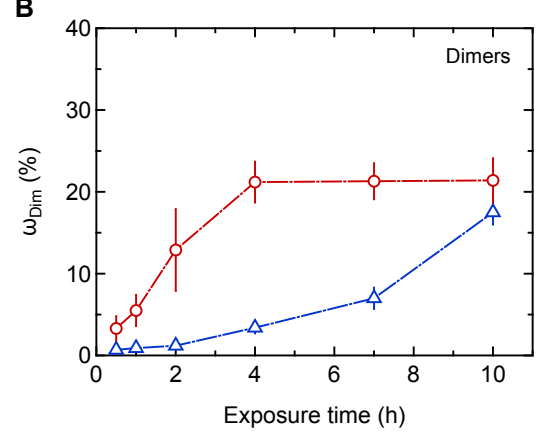

C

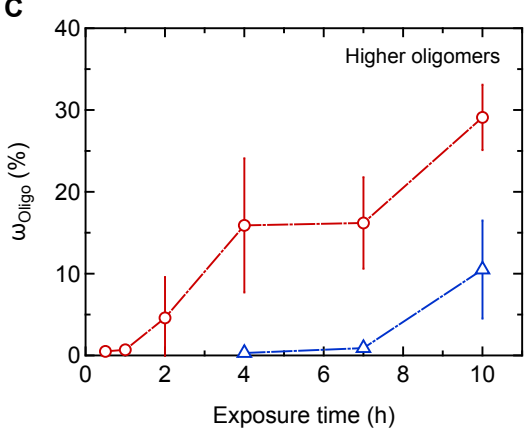

$-\triangle 50 \mathrm{ppb} \mathrm{O}_{3}, 50 \mathrm{ppb} \mathrm{NO} \mathrm{N}_{2} \multimap-200 \mathrm{ppb} \mathrm{O}_{3}, 200 \mathrm{ppb} \mathrm{NO}$

Figure 1. Oligomerization of Phl p 5 exposed to low (blue triangles) and high (red circles) concentrations of ozone $\left(\mathrm{O}_{3}\right)$ and nitrogen dioxide $\left(\mathrm{NO}_{2}\right)$ for different exposure times determined by size-exclusion chromatography (SEC-HPLC): Mass fractions of $(\mathbf{A})$ monomers $\left(\omega_{\text {Mon }}\right),(\mathbf{B})$ dimers $\left(\omega_{\text {Dim }}\right),(\mathbf{C})$ higher oligomers $\left(\mathrm{MW}>\mathrm{MW}_{\text {dimer }} ; \omega_{\text {Oligo }}\right)$. Arithmetic mean values and standard deviations of two to five independent experiments measured in duplicates, respectively. Lines are to guide the eye.

The mass fraction of higher oligomers $\left(\mathrm{MW}>\mathrm{MW}_{\text {dimer }}\right.$ ) showed a strong and gradual increase over time at high $\mathrm{O}_{3} / \mathrm{NO}_{2}$ concentrations. At low oxidant concentrations, however, the detection of higher oligomers was not possible at short exposure times, and a significant increase is only shown for long exposure times reaching $11 \pm 6 \%$ after $10 \mathrm{~h}$ of exposure (Figure 1C). The largest higher oligomer fraction (29 $\pm 4 \%$ ) was found for exposure to high $\mathrm{O}_{3} / \mathrm{NO}_{2}$ concentrations for $10 \mathrm{~h}$. The mass fraction of higher oligomers thus exceeds the dimer mass fraction at high oxidant concentrations and long exposure times. The corresponding mass fraction of Phl p 5 monomers decreased significantly over the course of exposure time, and the minimum Phl p 5 monomer mass fraction found in this study was $72 \pm 8 \%$ for low $\mathrm{O}_{3} / \mathrm{NO}_{2}$ concentrations and $50 \pm 2 \%$ for high oxidant concentrations (Figure 1A). As the monomer mass fraction continued to decline and the higher oligomer mass fraction continued to increase up to the $10 \mathrm{~h}$ mark, we expect an even larger fraction of higher oligomers for longer exposure times than those investigated in this study, while the dimer mass fraction will remain in a dynamic equilibrium of formation and consumption as long as protein monomers are available.

To investigate the effect of exposure to the single oxidants, we performed additional experiments using only $\mathrm{O}_{3}$ or only $\mathrm{NO}_{2}$. For the exposure to $200 \mathrm{ppb} \mathrm{O}_{3}$ for $2 \mathrm{~h}$, we found $20 \pm 1 \%$ of dimers and $15 \pm 3 \%$ of higher oligomers, which are both higher than those found for exposure to the mixture of $200 \mathrm{ppb} \mathrm{O}_{3}$ and $200 \mathrm{ppb} \mathrm{NO}$ over the same time. This could be explained by the underlying reaction mechanism, which was hypothesized previously to consist of two steps [40-42]. According to this mechanism, a tyrosine residue of the protein first reacts with $\mathrm{O}_{3}$ to form a tyrosyl radical as long-lived reactive oxygen intermediate (ROI) (R1). Due to their long lifetime ( $>10 \mathrm{~min}$ [42]), ROI may react in a second step either with $\mathrm{NO}_{2}$, resulting in the formation of 3-nitrotyrosine (NTyr) residues (R2), combine with other ROI forming dityrosine (DiTyr) cross-links (R3), or undergo further oxidation reactions. Our findings of lower oligomer mass fractions upon exposure to the mixture of 
$\mathrm{O}_{3} / \mathrm{NO}_{2}$ could be explained by a competition between $\mathrm{NO}_{2}$ and a second tyrosyl radical in the second reaction step once the ROI is formed.

$$
\begin{gathered}
\mathrm{Tyr}+\mathrm{O}_{3} \rightarrow \text { ROI } \\
\mathrm{ROI}+\mathrm{NO}_{2} \rightarrow \text { NTyr } \\
\mathrm{ROI}+\mathrm{ROI} \rightarrow \text { DiTyr }
\end{gathered}
$$

We also tested the effect of exposure to $200 \mathrm{ppb} \mathrm{NO}_{2}$ for $2 \mathrm{~h}$ without the addition of $\mathrm{O}_{3}$ and found a dimer mass fraction of $6 \pm 1 \%$, but no higher oligomers. This observation is unexpected as the reaction mechanism described above requires $\mathrm{O}_{3}$ for $\mathrm{ROI}$ formation [42]. Our findings show that ROI may also be formed by $\mathrm{NO}_{2}$, though at a lower rate (R4) $[19,43]$. The so formed ROI can then undergo further reactions as already described above (R2, R3).

$$
\mathrm{Tyr}+\mathrm{NO}_{2} \rightarrow \mathrm{ROI}
$$

A lower steady-state concentration of ROI compared to the mixed $\mathrm{O}_{3} / \mathrm{NO}_{2}$ experiments and the presence of sufficient $\mathrm{NO}_{2}$ leads to less formation of dimers, in line with the original mechanism. Alternatively, also other possible cross-linking site reactions such as e.g., the formation of protein carbonyl-lysin schiff bases may occur [44,45].

Figure 2 shows the effect of different concentrations of $\mathrm{ONOO}^{-}$on the oligomerization of Phl p 5. The largest oligomer mass fractions were found for equimolar concentrations of peroxynitrite and Tyr residues $\left(\mathrm{ONOO}^{-} /\right.$Tyr: $\left.1 / 1\right)$, reaching up to $26 \pm 1 \%$ for dimers and $18 \pm 5 \%$ for higher oligomers. The corresponding minimum mass fraction of monomers was $56 \pm 6 \%$. For higher molar ratios of $\mathrm{ONOO}^{-} / \mathrm{Tyr}$, however, lower oligomer mass fractions were found.

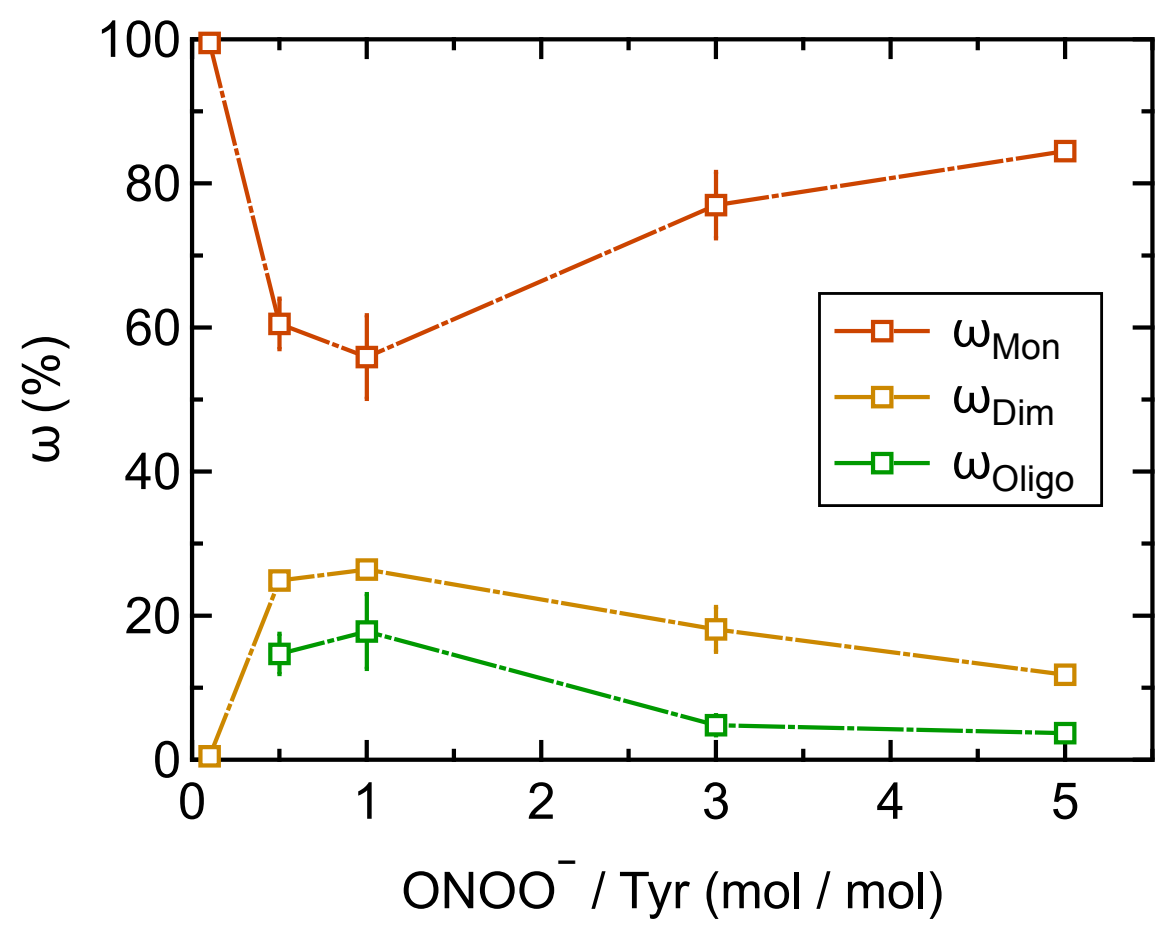

Figure 2. Protein oligomer mass fractions of $\mathrm{Phl} p 5$ treated with different molar ratios of peroxynitrite over tyrosine residues $\left(\mathrm{ONOO}^{-} / \mathrm{Tyr}\right)$ determined by SEC-HPLC: monomers $\left(\omega_{\text {Mon }}\right)$, dimers $\left(\omega_{\text {Dim }}\right)$ and higher oligomers $\left(\mathrm{MW}>\mathrm{MW}_{\text {dimer }} ; \omega_{\text {Oligo }}\right)$. Arithmetic mean values and standard deviations of two independent experiments measured in duplicates. Lines are to guide the eye. 
The formation of a dityrosine cross-link between two protein monomers by peroxynitrite is thought to be a two-step mechanism, in which first two tyrosyl radicals form that subsequently combine [34]. Ammonium bicarbonate buffer ensures alkaline reaction conditions and triggers the reaction of $\mathrm{ONOO}^{-}$with $\mathrm{CO}_{2}$ forming nitrosoperoxycarbonate $\left(\mathrm{ONOOCO}_{2}^{-}\right)$, which rapidly decomposes to $\mathrm{NO}_{2}$ and a carbonate radical $\left(\mathrm{CO}_{3}{ }^{-}\right)[46,47]$. Both radicals may react with the protein to form a tyrosyl radical; however, radical formation by $\mathrm{CO}_{3}{ }^{-}$is likely much faster and may thus be the dominant reaction pathway at excess concentrations of $\mathrm{ONOO}^{-}$. This scenario would lead to both high tyrosyl radical and high $\mathrm{NO}_{2}$ concentrations and hence favor protein nitration, which will be discussed below [48]. At low $\mathrm{ONOO}^{-}$concentrations, however, additional tyrosyl radical formation by $\mathrm{NO}_{2}$ would lead to tyrosyl radical formation at a comparatively low $\mathrm{NO}_{2}$ concentration, which would favor the formation of dimers and higher oligomers, in accordance with our observations. This is also in good agreement with Pfeiffer et al. [34], who found that the dimerization of Tyr radicals outcompeted the nitration reaction at low $\mathrm{ONOO}^{-}$concentrations.

SDS-PAGE analysis with silver stain of Phl $\mathrm{p} 5$ before and after exposure to $\mathrm{O}_{3} / \mathrm{NO}_{2}$ and reaction with $\mathrm{ONOO}^{-}$, respectively, was performed to confirm and visualize the size-exclusion chromatography results. The expected molecular masses of the Phlp 5 protein fractions are $28.6 \mathrm{kDa}$ for monomers, $57.2 \mathrm{kDa}$ for dimers, $85.8 \mathrm{kDa}$ for trimers, and $114.4 \mathrm{kDa}$ for tetramers. Figure 3 shows that native Phl p 5 mainly consists of monomers, and that these monomers were cross-linked to dimers and higher oligomers dependent on the reagent, its concentration, and exposure time.

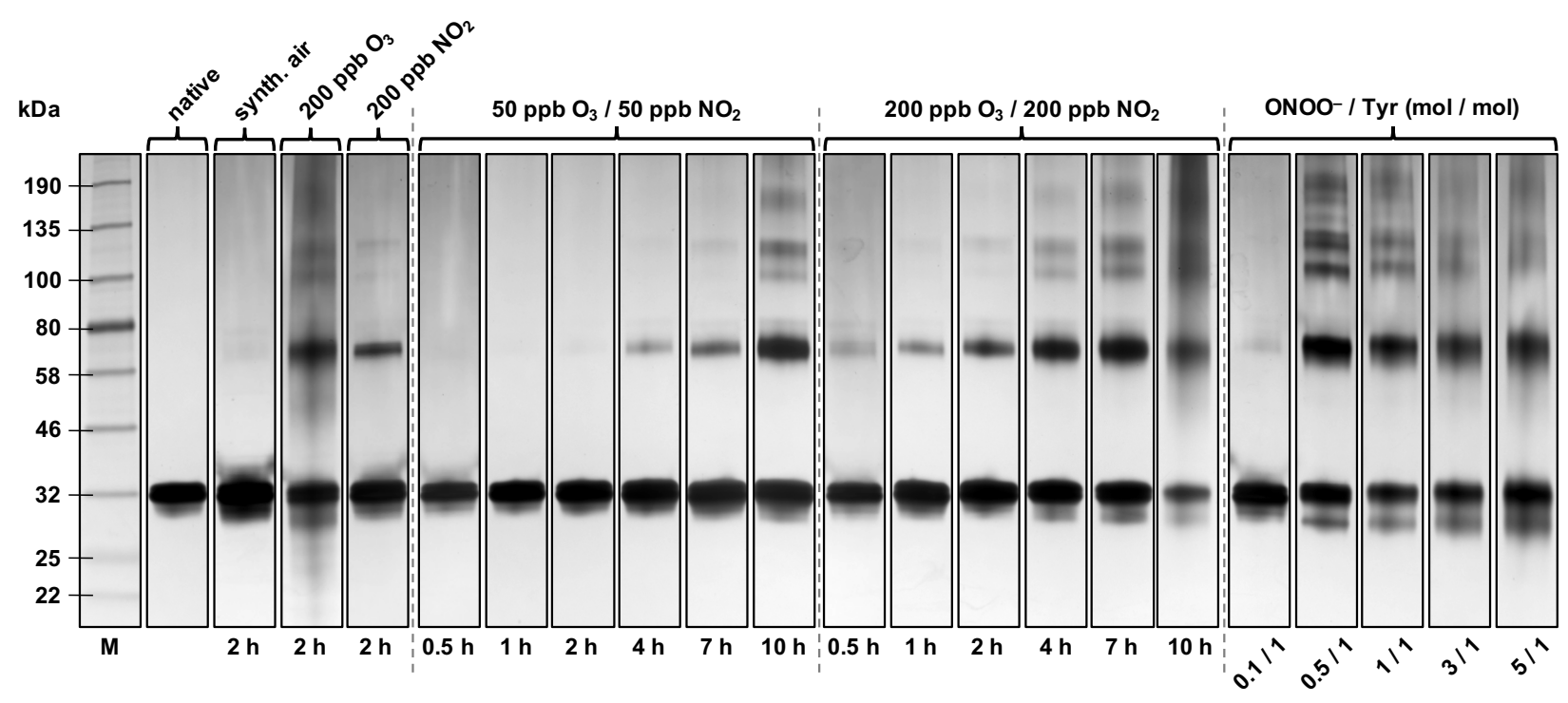

Figure 3. SDS-PAGE with silver stain for Phl p 5 before and after exposure to $\mathrm{O}_{3} / \mathrm{NO}_{2}$ and reaction with $\mathrm{ONOO}^{-}$, respectively. For each lane, $50 \mathrm{ng}$ Phl p 5 was loaded onto the gel. Expected molecular masses: monomer (28.6 kDa), dimer $(57.2 \mathrm{kDa})$, trimer $(85.8 \mathrm{kDa})$, and tetramer $(114.4 \mathrm{kDa})$.

A comparison of both experiments, exposure to $\mathrm{O}_{3} / \mathrm{NO}_{2}$ and reaction with $\mathrm{ONOO}^{-}$, reveals that significant formation of protein dimers and higher oligomers is achieved with either method. The total and relative amounts, however, depend on the exact reaction conditions. While the maximum dimer and higher oligomer mass fractions for the reaction with $\mathrm{ONOO}^{-}$were found at equimolar concentrations of $\mathrm{ONOO}^{-}$and tyrosine residues, we assume to find an even larger mass fraction of higher oligomers for exposure to $\mathrm{O}_{3} / \mathrm{NO}_{2}$ at longer exposure times than investigated in this study. It has to be taken into account that the exposure to $\mathrm{O}_{3} / \mathrm{NO}_{2}$ occurred in pure water, whereas for the reaction with $\mathrm{ONOO}^{-}$, the protein was further stabilized in a buffer solution. In pure water, the protein is directly exposed to the highly reactive gases $\mathrm{O}_{3}$ and $\mathrm{NO}_{2}$, that could additionally lead to protein 
denaturation and unfolding. Ke and Huang [49] reported that the protein structure and conformation can influence the efficiency of dityrosine cross-linking as they found that proteins in an unstructured state can be more easily cross-linked via dityrosine formation. Thus, partial unfolding of $\mathrm{Phl} \mathrm{p} 5$ in pure water could in part explain the high oligomerization degrees observed for the exposure to $\mathrm{O}_{3} / \mathrm{NO}_{2}$ in this study and may lead to sustained oligomerization at even longer exposure times.

\subsection{Nitration}

Native and modified Phl 55 samples were analyzed by reversed-phase chromatography (RP-HPLC) for their total tyrosine nitration degree, and the number of nitrotyrosine residues was calculated. For comparison, MALDI-TOF-MS experiments were performed with selected samples (for spectra, see Supplementary Materials Figure S2). Native Phl p 5 has a total tyrosine nitration degree $\left(\mathrm{ND}_{\text {tot }}\right)$ of $0.3 \%$, but all results of modified proteins shown in this study were not corrected for this value.

Figure 4 shows the total tyrosine nitration degree of Phl 55 at low ( $50 \mathrm{ppb} / 50 \mathrm{ppb})$ and high $(200 \mathrm{ppb} / 200 \mathrm{ppb})$ concentrations of $\mathrm{O}_{3}$ and $\mathrm{NO}_{2}$, determined by $\mathrm{UV}$ absorbance. $\mathrm{ND}_{\text {tot }}$ increased over the course of exposure time and with increasing $\mathrm{O}_{3} / \mathrm{NO}_{2}$ concentrations. For high oxidant concentrations, the curve runs asymptotically towards a maximum $\mathrm{ND}_{\text {tot }}$ of $9 \pm 1 \%$, which was reached after $10 \mathrm{~h}$ of exposure. Considering $12 \mathrm{Tyr}$ residues per Phl 55 molecule, the maximum $\mathrm{ND}_{\text {tot }}$ corresponds to an average of approx. one nitrotyrosine (NTyr) residue calculated per Phl p 5 monomer. Exposure at low $\mathrm{O}_{3} / \mathrm{NO}_{2}$ concentrations shows a gradual increase with exposure time, reaching a $\mathrm{ND}_{\text {tot }}$ of $5 \pm 1 \%$ after $10 \mathrm{~h}$. From extrapolation, we assume that at low oxidant concentrations, longer exposure times are needed to reach a similar maximum $\mathrm{ND}_{\text {tot }}$ as found for exposure at high oxidant concentrations.

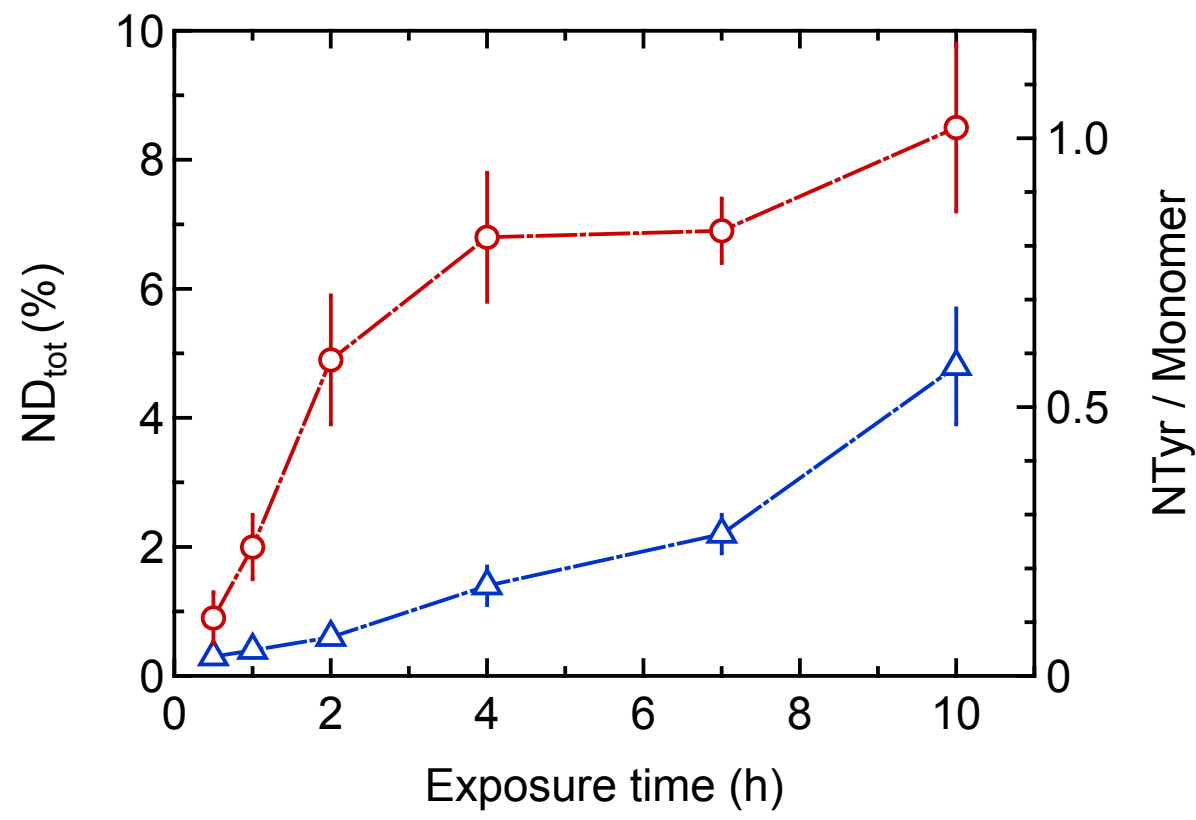

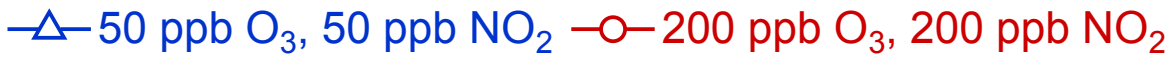

Figure 4. Total nitration degree ( $\mathrm{ND}_{\mathrm{tot}}$ ) of Phl $\mathrm{p} 5$ exposed to low (blue triangles) and high (red circles) concentrations of $\mathrm{O}_{3} / \mathrm{NO}_{2}$ determined by reversed-phase chromatography (RP-HPLC) (primary yaxis) and average number of nitrotyrosine (NTyr) residues calculated per Phl p 5 monomer (secondary $\mathrm{y}$-axis) for different exposure times. Arithmetic mean values and standard deviations of two to five independent experiments measured in duplicates. Lines are to guide the eye. 
These results are in good agreement with our previous study on the chemical modification of the major birch pollen allergen Bet $\mathrm{v} 1.0101$ by $\mathrm{O}_{3} / \mathrm{NO}_{2}$ in aqueous phase [28]. That study reported a nitration degree of $\sim 22 \pm 7 \%$ after $17 \mathrm{~h}$ of exposure at $120 \mathrm{ppb} \mathrm{O}_{3}$ and $120 \mathrm{ppb} \mathrm{NO}$. The reaction conditions are comparable to the ones used in this study (in total $\sim 2 \mathrm{ppm} \mathrm{h}$ of each gas), so that the absolute nitration degree was higher for Bet $\mathrm{v} 1$ compared to Phlp 5. Considering that the Betv 1 molecule contains in total only $7 \mathrm{Tyr}$ residues, the relative nitration degree per tyrosine residue is similar to the results obtained in this study. For both allergens, approx. one tyrosine residue was nitrated under the investigated conditions.

Figure 5 shows that the nitration degrees of protein monomers and dimers also increased gradually over the course of exposure time. The maximum nitration degree of monomers was $4 \pm 2 \%$ for low $\mathrm{O}_{3} / \mathrm{NO}_{2}$ concentrations and $7 \pm 1 \%$ for high oxidant concentrations after $10 \mathrm{~h}$ of exposure (Figure $5 \mathrm{~A}$ ), which is consistent with the results obtained by RP-HPLC for the total nitration degree. The maximum nitration degree for the Phl p 5 dimers was $9 \pm 1 \%$ for low $\mathrm{O}_{3} / \mathrm{NO}_{2}$ concentrations and $13 \pm 2 \%$ for high oxidant concentrations after $10 \mathrm{~h}$ of exposure (Figure $5 \mathrm{~B}$ ). For the higher oligomers ( $\mathrm{MW}>\mathrm{MW}_{\text {dimer }}$ ), the nitration degree could not be reliably quantified due to the low concentrations of the protein samples. Interestingly, the dimers seem to exhibit a higher nitration degree than the monomers. However, it cannot be fully excluded that other protein modifications such as dityrosine and hydroxytyrosine affect the determination of the nitration degree due to interference with the absorption spectrum of tyrosine and nitrotyrosine [50]. This hypothesis is supported by the results of the pure $\mathrm{O}_{3}$ exposure experiment, in which a total nitration degree of $3.5 \%$ was found, although no $\mathrm{NO}_{2}$ was applied. In this case, the formation of nitrotyrosine can be excluded and other modifications of the tyrosine residue must have inferred with the absorption spectrum and led to a slight positive bias in the nitration degree. It can thus not be determined with certainty that dimers are more strongly nitrated than monomers.

A

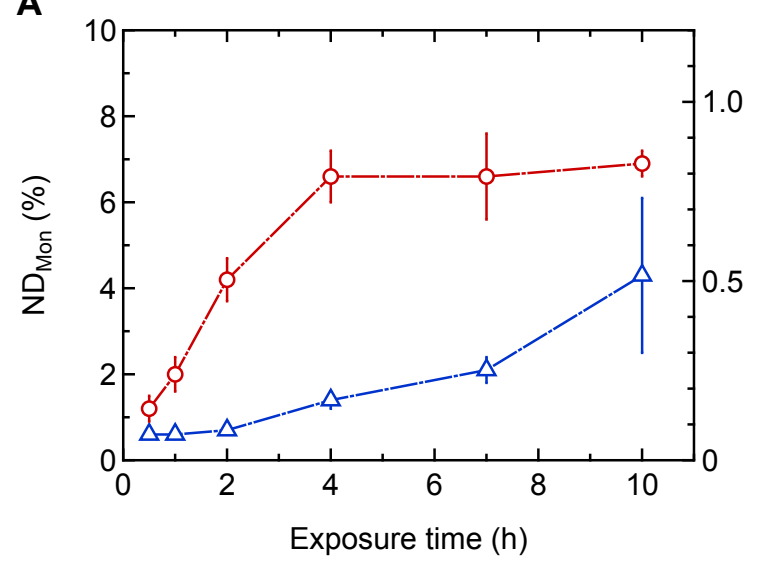

B

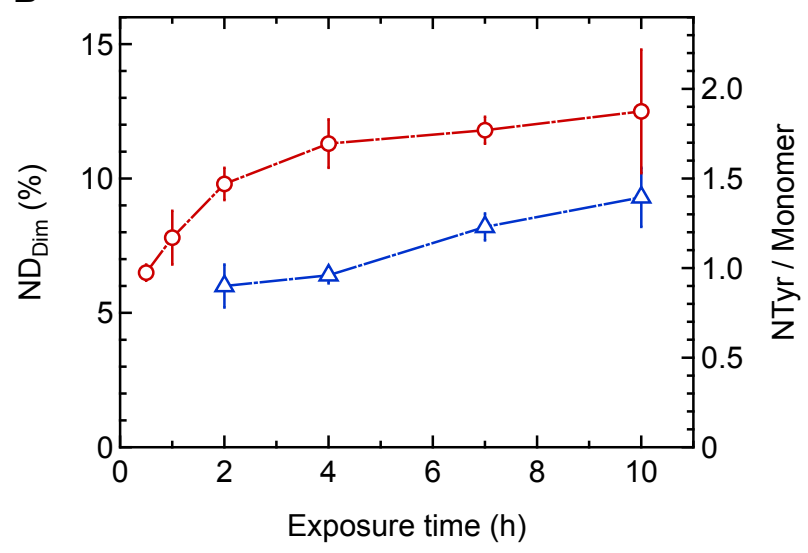

$\triangle-50 \mathrm{ppb} \mathrm{O}_{3}, 50 \mathrm{ppb} \mathrm{\textrm {NO } _ { 2 }}-\mathrm{-}-200 \mathrm{ppb} \mathrm{O}_{3}, 200 \mathrm{ppb} \mathrm{NO} \mathrm{N}_{2}$

Figure 5. Nitration degrees of different Phl 55 protein mass fractions determined by SEC-HPLC (primary y-axis) and average number of nitrotyrosine (NTyr) residues calculated per Phl p 5 monomer (secondary y-axis) for different exposure times: (A) monomers $\left(\mathrm{ND}_{\mathrm{Mon}}\right)$, (B) dimers $\left(\mathrm{ND}_{\text {Dim }}\right)$. Arithmetic mean values and standard deviations of two to five independent experiments measured in duplicates. Lines are to guide the eye.

Figure 6 shows the total tyrosine nitration degree for the reaction of peroxynitrite with $\mathrm{Phl} \mathrm{p}$ 5. Increasing the molar ratio of peroxynitrite over tyrosine $\left(\mathrm{ONOO}^{-} / \mathrm{Tyr}\right)$ resulted in an increasing $\mathrm{ND}_{\text {tot }}$. The curve runs asymptotically towards a maximum $\mathrm{ND}_{\text {tot }}$ of $25 \pm 3 \%$, which was reached for the $\mathrm{ONOO}^{-} /$Tyr molar ratio of $5 / 1$. Considering 12 Tyr residues per Phl p 5 molecule, the maximum $\mathrm{ND}_{\text {tot }}$ corresponds to an average of $\sim 3 \mathrm{NTyr}$ residues calculated per Phl p 5 monomer. 


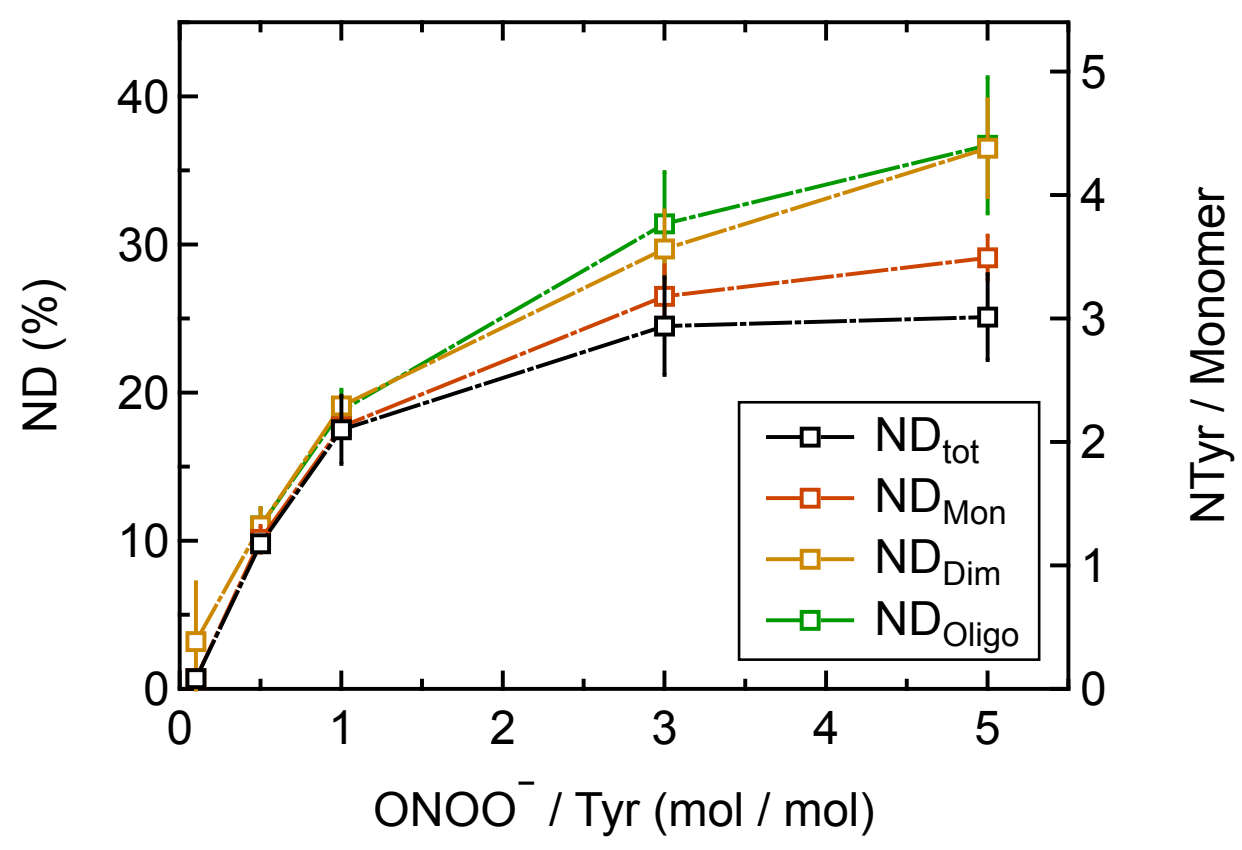

Figure 6. Total nitration degree determined by RP-HPLC and nitration degrees of different Phl p 5 protein mass fractions determined by SEC-HPLC (primary y-axis) as well as number of nitrotyrosine (NTyr) residues calculated per Phl p 5 monomer (secondary y-axis) for different molar ratios of peroxynitrite over tyrosine residues $\left(\mathrm{ONOO}^{-} / \mathrm{Tyr}\right)$. Arithmetic mean values and standard deviations of two to three independent experiments measured in duplicates. Lines are to guide the eye.

The tyrosine nitration degrees for Phl p 5 monomers, dimers, and higher oligomers increased with increasing molar ratio of peroxynitrite over tyrosine $\left(\mathrm{ONOO}^{-} / \mathrm{Tyr}\right)$ similar to $\mathrm{ND}_{\text {tot }}$ (Figure 6). The maximum nitration degree for the Phl p 5 monomers was $29 \pm 2 \%$, which corresponds to an average of $\sim 3.5$ NTyr residues calculated per Phl p 5 monomer. The maximum nitration degree for the Phl p 5 dimers was $37 \pm 3 \%$, which is higher than the monomers and corresponds to an average of $\sim 4.5 \mathrm{NTyr}$ residues calculated per Phl p 5 monomer. The maximum nitration degree for the higher oligomers $\left(\mathrm{MW}>\mathrm{MW}_{\text {dimer }}\right)$ was $37 \pm 5 \%$ and similar to the dimers. The nitration degrees for monomers, dimers, and higher oligomers appear to be higher than the total nitration degree. Here, it needs to be considered that the nitration degrees were determined by two different methods $\left(\mathrm{ND}_{\text {tot }}\right.$ : RP-HPLC at $\mathrm{pH} 3.5 ; \mathrm{ND}_{\mathrm{Mon}}, \mathrm{ND}_{\text {Dim }}, \mathrm{ND}_{\text {Oligo }}$ : SEC-HPLC at $\left.\mathrm{pH} 7\right)$. This $\mathrm{pH}$ change can affect the absorption spectrum of the modified amino acid residues [51,52]. Please note that for nitrotyrosine, the $\mathrm{pH}$ dependency of the NTyr extinction coefficient was already taken into consideration for both methods [53,54], but it might need to be considered for other modified amino acids as well.

In addition, the nitration results of the two protein modification methods were confirmed by MALDI measurements, exemplarily for selected samples (Table 1). The good agreement of results from UV absorbance and mass spectrometry suggests that primarily nitrotyrosine and no or only little other oxidation products were formed. The nitration and oxidation of other amino acids such as phenylalanine, however, cannot be excluded, but is rather unlikely based on previous studies $[28,55,56]$. 
Table 1. Oligomerization and nitration results of selected samples determined by UV absorbance and mass spectrometry (MS) exemplarily for one independent experiment.

\begin{tabular}{lccccc}
\hline & \multicolumn{3}{c}{ UV } & \multicolumn{2}{c}{ MS } \\
\cline { 2 - 5 } & DD (\%) & DiTyr & ND $_{\text {tot }}(\%)$ & NTyr & NTyr \\
\hline $\mathrm{O}_{3} / \mathrm{NO}_{2}(50 / 50 \mathrm{ppb}), 10 \mathrm{~h}$ & 2.0 & 0.2 & 4.5 & 0.5 & 0.4 \\
$\mathrm{O}_{3} / \mathrm{NO}_{2}(200 / 200 \mathrm{ppb}), 2 \mathrm{~h}$ & 2.8 & 0.3 & 6.2 & 0.7 & 0.7 \\
$\mathrm{O}_{3} / \mathrm{NO}_{2}(200 / 200 \mathrm{ppb}), 10 \mathrm{~h}$ & 5.0 & 0.6 & 9.6 & 1.2 & 2.0 \\
$\mathrm{ONOO}^{-} / \operatorname{Tyr}(1 / 1)$ & 3.6 & 0.4 & 16.8 & 2.6 & 1.1 \\
$\mathrm{ONOO}^{-} / \operatorname{Tyr}(3 / 1)$ & 2.4 & 0.3 & 21.9 & 2.6 & 2.6 \\
$\mathrm{ONOO}^{-} / \operatorname{Tyr}(5 / 1)$ & 1.5 & 0.2 & 21.8 & 2.7 \\
\hline
\end{tabular}

DD: Dityrosine degree; DiTyr: average number of dityrosine residues calculated per Phlp 5 monomer; $\mathrm{ND}_{\text {tot: }}$ total nitration degree determined by RP-HPLC; NTyr: average number of nitrotyrosine residues calculated per Phl p 5 monomer (UV: based on absorbance at 280 and $357 \mathrm{~nm}$; MS: calculated as nitro groups from peak shift).

Both exposure to $\mathrm{O}_{3} / \mathrm{NO}_{2}$ and reaction with $\mathrm{ONOO}^{-}$led to the formation of nitrotyrosine and thus to protein nitration. Comparing both protein modification pathways, we can conclude that under the conditions used in this study, the highest nitration degrees were found for the reaction with $\mathrm{ONOO}^{-}$. While at most only one tyrosine residue per Phl p 5 monomer could be nitrated upon exposure to $\mathrm{O}_{3} / \mathrm{NO}_{2}$, approximately three nitrotyrosine residues per Phl 5 monomer were found for the reaction with $\mathrm{ONOO}^{-}$. Moreover, other reactant concentrations, the different reaction media could play a role here. In the reaction with $\mathrm{ONOO}^{-}$, the proteins are stabilized in a buffer solution, but exposure to $\mathrm{O}_{3} / \mathrm{NO}_{2}$ occurs in pure water. The modifications of Phl p 5 could lead to conformational changes of the protein, which could result in an altered accessibility of the individual tyrosine residues for the different reagents. Moreover, the concentration of $\mathrm{ONOO}^{-}(2 \mathrm{mM})$ is much larger than the amount of dissolved $\mathrm{NO}_{2}$ from bubbling $(\sim 2 \mathrm{nM}$ using a Henry's law coefficient of $\sim 10^{-2} \mathrm{Matm}^{-1}[57]$ ), which may lead to a higher $\mathrm{NO}_{2}$ radical concentration in the experiments using $\mathrm{ONOO}^{-}$. However, without proper knowledge of the $\mathrm{ONOO}^{-}$decomposition kinetics, the in situ $\mathrm{NO}_{2}$ concentrations in aqueous solution could not be determined.

\subsection{Comparison Oligomerization Vs. Nitration}

For a better comparison of protein oligomerization and nitration in this study, but also with other proteins from related studies, we calculated how many tyrosine residues on average were cross-linked in dityrosines. The so-called dityrosine degree (DD) enables the direct comparison of modifications on tyrosine level and thus takes into account the total amount of tyrosine residues in a protein. Table 1 shows the dityrosine degree and the average number of tyrosine residues, which were cross-linked in dityrosines, calculated per Phl p 5 monomer in comparison to the nitration results for selected samples. Evidently, protein nitration occurs more readily than protein oligomerization as nitration degrees are larger than dityrosine degrees for all investigated samples. Figure 7 shows the temporal evolution of nitrated and cross-linked tyrosine residues for the samples, which were exposed to low (A) and high (B) concentrations of $\mathrm{O}_{3} / \mathrm{NO}_{2}$, and the concentration dependency of nitrated and cross-linked tyrosine residues for the reaction with $\mathrm{ONOO}^{-}(\mathrm{C})$. The direct comparison of nitrated tyrosine residues and those cross-linked in dityrosines shows that more tyrosine residues were nitrated than cross-linked under the same conditions. Considering the reaction mechanisms for both exposure to $\mathrm{O}_{3} / \mathrm{NO}_{2}$ and reaction with $\mathrm{ONOO}^{-}$, this is not that surprising, as in the competition for the ROI, the $\mathrm{NO}_{2}$ radical is sterically at an advantage compared to the rather bulky secondary ROI. Furthermore, there should be much more $\mathrm{NO}_{2}$ radicals than $\mathrm{ROI}$ in the reaction mixture, so that the reaction of ROI with $\mathrm{NO}_{2}$ is more likely compared to the combination of two ROI. This hypothesis is in agreement with an earlier study of the model protein bovine serum albumin (BSA), which found that protein nitration is favored over protein oligomerization [41]. The influence of protein concentration on the oligomerization and nitration, however, will be investigated in future studies. 
A

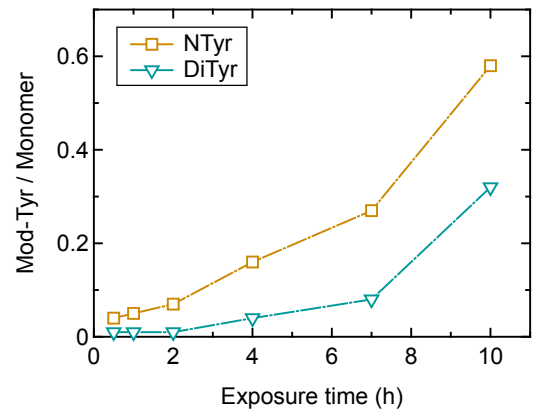

B

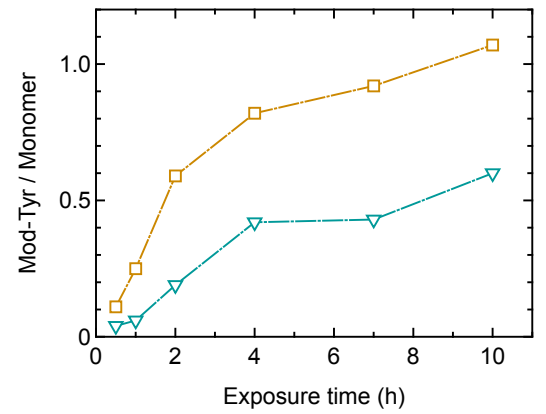

C

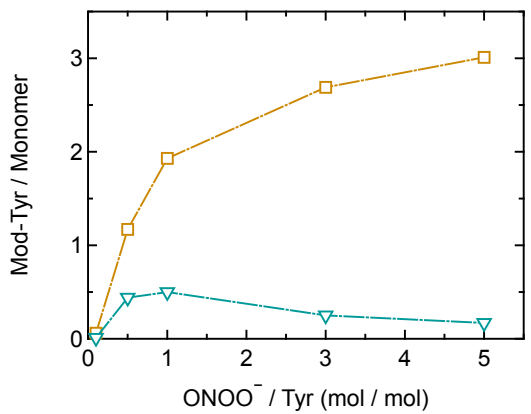

Figure 7. Nitrated and cross-linked tyrosine residues calculated per Phl p 5 monomer after exposure to low (A) and high (B) $\mathrm{O}_{3} / \mathrm{NO}_{2}$ concentrations and reaction with $\mathrm{ONOO}^{-}(\mathbf{C})$. Lines are to guide the eye.

The concentrations of $\mathrm{O}_{3}$ and $\mathrm{NO}_{2}$ used in this study are close to levels typically encountered in the atmosphere. The world health organization (WHO) set the guideline value for ozone levels to $100 \mathrm{\mu g} \mathrm{m}^{-3}$ (approx. $50 \mathrm{ppb}$ ) for an 8-hour daily average to provide adequate protection of public health, while the European union transposed the directive to a limit of $120 \mathrm{\mu g} \mathrm{m}^{-3}$. In Germany, the annual mean was on average $51 \mu \mathrm{g} \mathrm{m}^{-3}$ for the years 1995 to 2019, and the EU level was exceeded on average on 22 days per year in this time period [58,59]. The WHO guideline value for nitrogen dioxide was set to $200 \mathrm{\mu g} \mathrm{m}^{-3}$ (approx. $100 \mathrm{ppb}$ ) for an 1-h mean and $40 \mathrm{\mu g} \mathrm{m}^{-3}$ for an annual mean. In Germany, the $\mathrm{NO}_{2}$ emissions are decreasing over recent decades, and they were on average $25 \mu \mathrm{g} \mathrm{m}{ }^{-3}$ in 2019, but $12 \%$ of the measurement stations exceeded the limit of the annual mean [60].

The peroxynitrite concentrations in the human body, however, are difficult to determine precisely, as the strong oxidizing and nitrating reagent is formed in vivo during oxidative stress and inflammation from nitrogen oxide radicals $(\mathrm{NO})$ and superoxide anions $\left(\mathrm{O}_{2}{ }^{-}\right)$[32]. Kouti et al. [61] found peroxynitrite serum levels of $\sim 7 \mu \mathrm{mol} \mathrm{L}{ }^{-1}$ in patients with Parkinson's disease and $\sim 4 \mu \mathrm{mol} \mathrm{L}{ }^{-1}$ in the control group, which is less than we used in our study. It cannot be excluded, however, that higher peroxynitrite concentrations might occur at inflammation sites.

The products of the reactions of $\mathrm{O}_{3}, \mathrm{NO}_{2}$, and $\mathrm{ONOO}^{-}$with $\mathrm{Phl} p 5$ include various nitrated and cross-linked proteins, all of which might have a different allergenic potential. Until now, most studies focused on protein nitration as a potential enhancer for allergic and other severe diseases (e.g., $[19,26,27])$, but also other modifications such as protein cross-linking need to be considered. Thus, further studies are required to investigate the immunogenicity of the different nitrated and cross-linked variants, to complement the information on reaction kinetics obtained in this study. Furthermore, realistic and relevant mixtures of nitrated and cross-linked proteins are necessary to assess the whole health-related potential of modified proteins and elucidate their role in modulated immune responses. The efficient oligomerization and nitration of allergenic proteins by air pollutants and the enhanced allergenic and immunostimulatory potential of chemically modified proteins call for action to improve air quality and public health in the Anthropocene.

\section{Materials and Methods}

Pure water was taken from a Barnstead ${ }^{\mathrm{TM}}$ GenPure $^{\mathrm{TM}} \mathrm{xCAD}$ plus water purification system (Thermo Scientific, Braunschweig, Germany). The water was autoclaved at $121^{\circ} \mathrm{C}$ for $20 \mathrm{~min}$ and filtered three times through a sterile $0.1 \mu \mathrm{m}$ pore diameter polyethersulfone (PES) vacuum filter unit (VWR International, Radnor, PA, USA). Recombinant timothy grass (Phleum pratense) pollen allergen 5 (Phl p 5.0101) was obtained from Biomay AG (Vienna, Austria), and a stock solution $\left(1 \mathrm{mg} \mathrm{mL}^{-1}\right)$ was prepared with pure water prior to each experiment. The solution was reconstituted at room temperature for at least $30 \mathrm{~min}$ to ensure complete reconstitution of the protein. Sodium peroxynitrite $(160-200 \mathrm{mM})$ was purchased from Merck (Darmstadt, Germany), and ammonium bicarbonate $\left(\mathrm{NH}_{4} \mathrm{HCO}_{3}\right)$, acetonitrile (ACN), Tris-HCl, Glycerol, SDS, and monobasic sodium phosphate monohy- 
drate $\left(\mathrm{NaH}_{2} \mathrm{PO}_{4} \cdot \mathrm{H}_{2} \mathrm{O}\right)$ were from Carl Roth $\mathrm{GmbH} \& \mathrm{Co}$. KG (Karlsruhe, Germany). A $150 \mathrm{mM} \mathrm{NaH} \mathrm{PO}_{4} \cdot \mathrm{H}_{2} \mathrm{O}$ buffer was prepared, and the $\mathrm{pH}$ was adjusted to 7 by the addition of sodium hydroxide $(\mathrm{NaOH}) . \mathrm{NaOH}$ and water with $0.1 \%$ trifluoroacetic acid (TFA) were obtained from VWR International GmbH (Darmstadt, Germany). $\alpha$-Cyano-4hydroxycinnamic acid (HCCA, ultrapure, J67635) was purchased from Th. Geyer GmbH \& Co. KG (Renningen, Germany). Trifluoroacetic acid (TFA, LC-MS grade, 85183) was obtained from Thermo Fisher Scientific (Braunschweig, Germany).

\subsection{Protein Modification by $\mathrm{O}_{3} / \mathrm{NO}_{2}$}

The experimental setup was described previously [41], and it was extended by incorporating an oven (Heratherm IGS60, Thermo Fisher Scientific) to maintain a constant temperature of $25^{\circ} \mathrm{C}$ during the exposure. A schematic of the experimental setup is available in the Supplementary Materials Figure S3. Briefly, $\mathrm{O}_{3}$ was generated by synthetic air passing through a UV lamp (L.O.T.-Oriel GmbH \& Co. KG, Darmstadt, Germany) at $\sim 1.9 \mathrm{~L} \mathrm{~min}^{-1}$, and the $\mathrm{O}_{3}$ concentration was adjusted by tuning the amount of UV light. The gas flow was humidified by passing through a Nafion ${ }^{\circledR}$ gas humidifier (MH-110-12F-4, PermaPure, Lakewood, NJ, USA) operated with pure water. The gas flow was mixed with $\mathrm{N}_{2}$ containing $\sim 5 \mathrm{ppmV} \mathrm{NO}{ }_{2}$ (Air Liquide Deutschland $\mathrm{GmbH}$, Düsseldorf, Germany), and the $\mathrm{NO}_{2}$ concentration was regulated by the amount of the added $\sim 5 \mathrm{ppmV} \mathrm{NO} 2$ gas. After mixing, the gas flow was split, and one flow was used to react with the samples, and the other one was used to determine the concentrations of $\mathrm{O}_{3}$ and $\mathrm{NO}_{2}$. For sample exposure, the $\mathrm{O}_{3} / \mathrm{NO}_{2}$ gas mixture was directly bubbled through $1.5 \mathrm{~mL}$ of $0.13 \mathrm{mg} \mathrm{mL}^{-1}$ Phl p 5 aqueous solution at a flow rate of $60 \mathrm{~mL} \mathrm{~min}^{-1}$ using a Teflon tube (ID: $1.59 \mathrm{~mm}$ ). exposure times were $0.5,1,2,4,7$, and $10 \mathrm{~h}$, respectively. The $\mathrm{O}_{3}$ and $\mathrm{NO}_{2}$ concentrations were monitored using commercial monitoring instruments (ozone analyzer: 49i, Thermo Scientific, Braunschweig, Germany; NOx analyzer: T200UP, Teledyne API, San Diego, CA, USA).

After exposure, the samples were concentrated using a $10 \mathrm{kDa}$ centrifugal filter (Amicon ${ }^{\circledR}$ Ultra; Merck). For this, the reaction solution was pipetted into the filter unit and centrifuged at $14,000 \times g$ for $2 \mathrm{~min}$ (5427 R, Eppendorf). The sample was washed five times with $200 \mu \mathrm{L}$ pure water and centrifuged at $14,000 \times g$ for $2 \mathrm{~min}$. For sample recovery, the filter was turned upside down into a clean micro centrifuge tube and centrifuged at $1000 \times g$ for $2 \mathrm{~min}$. To remove possible sample residues, the filter was washed with $100 \mu \mathrm{L}$ pure water and centrifuged again upside down into the concentrated protein sample. Two to five independent experiments were performed.

\subsection{Protein Modification by $\mathrm{ONOO}^{-}$}

For each reaction, $300 \mu \mathrm{L}$ Phl p 5 protein stock solution $\left(1 \mathrm{mg} \mathrm{mL}^{-1}\right)$ was transferred into a brown reaction tube (Eppendorf, Hamburg, Germany), and $7.7 \mu \mathrm{LNH}_{4} \mathrm{HCO}_{3}$ buffer $(2 \mathrm{M})$ was added to yield a final buffer concentration of $0.05 \mathrm{M}$. Phl p 5 was treated with different peroxynitrite concentrations $(0.04-2 \mathrm{mM})$, which were applied in relation to the tyrosine content of the protein $\left(\mathrm{ONOO}^{-} / \mathrm{Tyr}\right.$ molar ratios: $\left.0.1 / 1,0.5 / 1,1 / 1,3 / 1,5 / 1\right)$. After being thawed on ice, an aliquot of peroxynitrite was diluted $1: 2$ with $0.3 \mathrm{M} \mathrm{NaOH}$ to reduce the pipetting error for small volumes. The diluted peroxynitrite solution was added to the protein sample to yield $\mathrm{ONOO}^{-} /$Tyr molar ratios of $0.1 / 1$ and $0.5 / 1$, and the original peroxynitrite solution was added to yield $\mathrm{ONOO}^{-} /$Tyr molar ratios of $1 / 1$, $3 / 1$, and $5 / 1$. The reaction was performed on ice for $110 \mathrm{~min}$. Afterwards, the sample was purified and concentrated using a $10 \mathrm{kDa}$ centrifugal filter as described in Section 3.1. Three independent experiments were performed.

\subsection{HPLC-DAD Analysis}

The protein oligomer mass fractions and their individual nitration degrees were determined simultaneously as previously described in Liu et al. [53] using a high-performance liquid chromatography system coupled to diode array detection (HPLC-DAD; Agilent 
Technologies 1260 Infinity II series), which consisted of a binary pump (G7112B), a multisampler (G7167A), a column thermostat (G7116A), and a photodiode array detector (G7115A) monitoring 220, 280, and $357 \mathrm{~nm}$. ChemStation software (Rev. C.01.08, Agilent) was used for system control and data analysis. Molecular weight separation by size-exclusion chromatography (SEC-HPLC) was carried out using a SEC column (PSS Proteema BioInert Micro $300 \AA$, $250 \mathrm{~mm} \times 4.6 \mathrm{~mm}$ inner diameter, $3 \mu \mathrm{m}$ particle size; PSS Polymer Standards Service GmbH, Mainz, Germany). Isocratic separation was performed at a flow rate of $0.35 \mathrm{~mL} \mathrm{~min}^{-1}$ with $150 \mathrm{mMNaH}_{2} \mathrm{PO}_{4}$ buffer (pH 7). The sample injection volume was $30 \mu \mathrm{L}$, and each chromatographic run was performed in duplicate.To calculate the number of tyrosine residues that are part of dityrosine cross-links, it was assumed for simplification that all higher oligomers are trimers. The protein mass fractions were divided by 100 , and the result of the higher oligomer mass fraction was multiplied by $4 / 3$ and added to the result of the dimer mass fraction to obtain the average number of cross-linked tyrosine (DiTyr) residues calculated per Phl p 5 monomer. The dityrosine degree (DD) was calculated by dividing the DiTyr number by 12, as each Phl p 5 monomer contains 12 tyrosine residues, and multiplying by 100 .

The total tyrosine nitration degree was determined as described in Selzle et al. [54]. Briefly, a HPLC-DAD system (Agilent Technologies 1260 Infinity series, Waldbronn, Germany) was used, which consisted of a quaternary pump (G1311B), an autosampler (G7129A), a column thermostat (G1316C), and a photodiode array detector (G1315C) monitoring 220, 280, and $357 \mathrm{~nm}$. ChemStation software (Rev. C.01.07, Agilent) was used for system control and data analysis. A monomerically bound $\mathrm{C}_{18}$ column (Vydac 238TP, $250 \mathrm{~mm} \times 2.1 \mathrm{~mm}$ i.d., $5 \mu \mathrm{m}$, Hichrom, Berkshire, UK) was used for reversed-phase chromatography (RP-HPLC). Gradient elution was performed at a flow rate of $0.2 \mathrm{~mL} \mathrm{~min}^{-1}$ with $0.1 \%(v / v)$ TFA in water and ACN. The sample injection volume was $10 \mu \mathrm{L}$, and each chromatographic run was performed in duplicate. To calculate the average number of nitrotyrosine (NTyr) residues per Phl p 5 monomer, the total nitration degree was multiplied by 12 , which is the number of tyrosine residues per Phl p 5 monomer.

\subsection{MALDI-TOF-MS Analysis}

MALDI-TOF-MS was performed on a Bruker Autoflex maX ${ }^{\mathrm{TM}}$ in linear mode. $\alpha-$ Cyano-4-hydroxycinnamic acid $\left(15 \mathrm{mg} \mathrm{mL}^{-1}\right.$ in $50 \% \mathrm{H}_{2} \mathrm{O}, 49.9 \% \mathrm{ACN}, 0.1 \%$ TFA $\left.(v / v / v)\right)$ was used as the matrix. Samples were spotted using the dried-droplet method with $1 \mu \mathrm{L}$ of sample solution and $1 \mu \mathrm{L}$ of matrix solution. The obtained spectra were averaged over 5000 laser shots. The average number of nitrotyrosine (NTyr) residues per Phl p 5 monomer was calculated as nitro groups from the peak shift between native and modified sample.

\subsection{SDS-PAGE and Silver Stain}

Native and modified Phl p 5 samples were mixed with an equivalent volume of $2 \times$ Laemmli buffer, containing 65.8 mM Tris- $\mathrm{HCl}(\mathrm{pH} 6.8), 26.3 \%$ glycerol $(v / v), 2.1 \%$ SDS and $0.01 \%$ bromophenol blue, and heated at $95^{\circ} \mathrm{C}$ for $5 \mathrm{~min}$. $50 \mathrm{ng}$ per sample were loaded onto a PROTEAN Precast gel (4-20\%, Bio-Rad, Munich, Germany) together with 60 ng Color Prestained Protein Standard, Broad Range (11-245 kDa, New-England Biolabs, Frankfurt, Germany). The gel was run at $200 \mathrm{~V}$ for $45 \mathrm{~min}$, and afterwards stained with a silver stain kit (Thermo Fisher Scientific) following manufacturer's instructions. For image acquisition, a ChemiDoc system (Bio-Rad) with Image Lab software 6.1 (Bio-Rad) was used.

Supplementary Materials: The following are available online at https://www.mdpi.com/1422-0 067/22/14/7616/s1, Figure S1: Exemplary chromatograms from the SEC-DAD analysis of Phl p5; Figure S2: MALDI spectra of selected samples; Figure S3: Experimental setup used for the exposure of Phl 5 to $\mathrm{O}_{3}$ and $\mathrm{NO}_{2}$.

Author Contributions: Conceptualization, supervision, project administration, M.G.W., U.P. and J.F.-N.; investigation, A.T.B., K.R.-S., A.L.L., K.Z., C.S.K. and G.T.; formal analysis, visualization, A.T.B.; writing —original draft preparation, A.T.B. and J.F.N.; writing—review and editing, A.T.B., 
K.R.-S., A.L.L., K.L., M.G.W., T.B., U.P. and J.F.-N. All authors have read and agreed to the published version of the manuscript.

Funding: K.Z. received funding from the Max Planck Graduate Center with the Johannes Gutenberg University (MPGC).

Institutional Review Board Statement: Not applicable.

Informed Consent Statement: Not applicable.

Data Availability Statement: The data presented in this study are openly available in an Edmond Repository at https:/ / doi.org/10.17617/3.6f, accessed on 1 June 2021.

Acknowledgments: We thank N. Bothen, N.-M. Kropf, U. Kuhn, and C. Wieder for technical assistance, M. L. Pöhlker, and B. Sánchez-Parra for helpful discussions, and the Max Planck Society (MPG) for financial support.

Conflicts of Interest: The authors declare no conflict of interest.

\section{Abbreviations}

The following abbreviations are used in this manuscript:

DiTyr Dityrosine

DD Dityrosine degree

MS Mass spectrometry

ND Nitration degree

NTyr Nitrotyrosine

RNS Reactive nitrogen species

ROI Reactive oxygen intermediate

ROS Reactive oxygen species

RP Reversed-phase chromatography

SEC Size-exclusion chromatography

Tyr Tyrosine

\section{References}

1. Asher, M.I.; Montefort, S.; Björkstén, B.; Lai, C.K.W.; Strachan, D.P.; Weiland, S.K.; Williams, H. Worldwide time trends in the prevalence of symptoms of asthma, allergic rhinoconjunctivitis, and eczema in childhood: ISAAC Phases One and Three repeat multicountry cross-sectional surveys. Lancet 2006, 368, 733-743. [CrossRef]

2. Li, X.; Song, P.; Zhu, Y.; Lei, H.; Chan, K.Y.; Campbell, H.; Theodoratou, E.; Rudan, I. The disease burden of childhood asthma in China: A systematic review and meta-analysis. J. Glob. Health 2020, 10, 010801. [CrossRef] [PubMed]

3. Pawankar, R. Allergic diseases and asthma: A global public health concern and a call to action. World Allergy Organ. J. 2014, 7, 12. [CrossRef]

4. Singh, S.; Sharma, B.B.; Salvi, S.; Chhatwal, J.; Jain, K.C.; Kumar, L.; Joshi, M.K.; Pandramajal, S.B.; Awasthi, S.; Bhave, S.; et al. Allergic rhinitis, rhinoconjunctivitis, and eczema: Prevalence and associated factors in children. Clin. Respir. J. 2018, 12, 547-556. [CrossRef] [PubMed]

5. Zhang, Y.; Zhang, L. Increasing Prevalence of Allergic Rhinitis in China. Allergy Asthma. Immunol. Res. 2019, 11, 156-169. [CrossRef]

6. D'Amato, G.; Baena-Cagnani, C.E.; Cecchi, L.; Annesi-Maesano, I.; Nunes, C.; Ansotegui, I.; D'Amato, M.; Liccardi, G.; Sofia, M.; Canonica, W.G. Climate change, air pollution and extreme events leading to increasing prevalence of allergic respiratory diseases. Multidiscip. Respir. Med. 2013, 8, 12. [CrossRef]

7. Eguiluz-Gracia, I.; Mathioudakis, A.G.; Bartel, S.; Vijverberg, S.J.H.; Fuertes, E.; Comberiati, P.; Cai, Y.S.; Tomazic, P.V.; Diamant, Z.; Vestbo, J.; et al. The need for clean air: The way air pollution and climate change affect allergic rhinitis and asthma. Allergy 2020, 75, 2170-2184. [CrossRef]

8. Pawankar, R.; Baena-Cagnani, C.E.; Bousquet, J.; Walter Canonica, G.; Cruz, A.A.; Kaliner, M.A.; Lanier, B.Q.; Henley, K. State of World Allergy Report 2008: Allergy and Chronic Respiratory Diseases. World Allergy Organ. J. 2008, 1, S4-S17. [CrossRef] [PubMed]

9. Traidl-Hoffmann, C.; Jakob, T.; Behrendt, H. Determinants of allergenicity. J. Allergy Clin. Immunol. 2009, 123, 558-566. [CrossRef]

10. Bowatte, G.; Lodge, C.J.; Knibbs, L.D.; Lowe, A.J.; Erbas, B.; Dennekamp, M.; Marks, G.B.; Giles, G.; Morrison, S.; Thompson, B.; et al. Traffic-related air pollution exposure is associated with allergic sensitization, asthma, and poor lung function in middle age. J. Allergy Clin. Immunol. 2017, 139, 122-129. [CrossRef] [PubMed] 
11. Deng, Q.; Lu, C.; Yu, Y.; Li, Y.; Sundell, J.; Norbäck, D. Early life exposure to traffic-related air pollution and allergic rhinitis in preschool children. Respir. Med. 2016, 121, 67-73. [CrossRef] [PubMed]

12. Guarnieri, M.; Balmes, J.R. Outdoor air pollution and asthma. Lancet 2014, 383, 1581-1592. [CrossRef]

13. Bryce, M.; Drews, O.; Schenk, M.F.; Menzel, A.; Estrella, N.; Weichenmeier, I.; Smulders, M.J.; Buters, J.; Ring, J.; Gorg, A.; et al. Impact of urbanization on the proteome of birch pollen and its chemotactic activity on human granulocytes. Int. Arch. Allergy Immunol. 2010, 151, 46-55. [CrossRef]

14. Ghiani, A.; Aina, R.; Asero, R.; Bellotto, E.; Citterio, S. Ragweed pollen collected along high-traffic roads shows a higher allergenicity than pollen sampled in vegetated areas. Allergy 2012, 67, 887-894. [CrossRef]

15. Motta, A.C.; Marliere, M.; Peltre, G.; Sterenberg, P.A.; Lacroix, G. Traffic-related air pollutants induce the release of allergencontaining cytoplasmic granules from grass pollen. Int. Arch. Allergy Immunol. 2006, 139, 294-298. [CrossRef]

16. Ouyang, Y.; Xu, Z.; Fan, E.; Li, Y.; Zhang, L. Effect of nitrogen dioxide and sulfur dioxide on viability and morphology of oak pollen. Int. Forum. Allergy Rhinol. 2016, 6, 95-100. [CrossRef]

17. Taylor, P.E.; Flagan, R.C.; Valenta, R.; Glovsky, M.M. Release of allergens as respirable aerosols: A link between grass pollen and asthma. J. Allergy Clin Immunol. 2002, 109, 51-56. [CrossRef]

18. Taylor, P.E.; Flagan, R.C.; Miguel, A.G.; Valenta, R.; Glovsky, M.M. Birch pollen rupture and the release of aerosols of respirable allergens. Clin. Exp. Allergy 2004, 34, 1591-1596. [CrossRef] [PubMed]

19. Franze, T.; Weller, M.G.; Niessner, R.; Pöschl, U. Protein Nitration by Polluted Air. Environ. Sci. Technol. 2005, 39, 1673-1678. [CrossRef] [PubMed]

20. Miguel, A.G.; Cass, G.R.; Glovsky, M.M.; Weiss, J. Allergens in Paved Road Dust and Airborne Particles. Environ. Sci. Technol. 1999, 33, 4159-4168. [CrossRef]

21. Shiraiwa, M.; Selzle, K.; Yang, H.; Sosedova, Y.; Ammann, M.; Pöschl, U. Multiphase chemical kinetics of the nitration of aerosolized protein by ozone and nitrogen dioxide. Environ. Sci. Technol. 2012, 46, 6672-6680. [CrossRef] [PubMed]

22. Abello, N.; Kerstjens, H.A.M.; Postma, D.S.; Bischoff, R. Protein Tyrosine Nitration: Selectivity, Physicochemical and Biological Consequences, Denitration, and Proteomics Methods for the Identification of Tyrosine-Nitrated Proteins. J. Proteome Res. 2009, 8, 3222-3238. [CrossRef] [PubMed]

23. Ackaert, C.; Kofler, S.; Horejs-Hoeck, J.; Zulehner, N.; Asam, C.; von Grafenstein, S.; Fuchs, J.E.; Briza, P.; Liedl, K.R.; Bohle, B.; et al. The impact of nitration on the structure and immunogenicity of the major birch pollen allergen Bet v 1.0101. PLoS ONE 2014, 9, e104520. [CrossRef] [PubMed]

24. Greenacre, S.A.B.; Ischiropoulos, H. Tyrosine nitration: Localisation, quantification, consequences for protein function and signal transduction. Free. Radic. Res. 2001, 34, 541-581. [CrossRef]

25. Ischiropoulos, H. Protein tyrosine nitration-an update. Arch. Biochem. Biophys. 2009, 484, 117-121. [CrossRef]

26. Gruijthuijsen, Y.K.; Grieshuber, I.; Stöcklinger, A.; Tischler, U.; Fehrenbach, T.; Weller, M.G.; Vogel, L.; Vieths, S.; Pöschl, U.; Duschl, A. Nitration Enhances the Allergenic Potential of Proteins. Int. Arch. Allergy Immunol. 2006, 141, 265-275. [CrossRef]

27. Karle, A.C.; Oostingh, G.J.; Mutschlechner, S.; Ferreira, F.; Lackner, P.; Bohle, B.; Fischer, G.F.; Vogt, A.B.; Duschl, A. Nitration of the pollen allergen bet $\mathrm{v} 1.0101$ enhances the presentation of bet $\mathrm{v}$ 1-derived peptides by HLA-DR on human dendritic cells. PLoS ONE 2012, 7, e31483. [CrossRef]

28. Reinmuth-Selzle, K.; Ackaert, C.; Kampf, C.J.; Samonig, M.; Shiraiwa, M.; Kofler, S.; Yang, H.; Gadermaier, G.; Brandstetter, H.; Huber, C.G.; et al. Nitration of the birch pollen allergen Bet v 1.0101: Efficiency and site-selectivity of liquid and gaseous nitrating agents. J. Proteome Res. 2014, 13, 1570-1577. [CrossRef] [PubMed]

29. Lakey, P.S.; Berkemeier, T.; Tong, H.; Arangio, A.M.; Lucas, K.; Poschl, U.; Shiraiwa, M. Chemical exposure-response relationship between air pollutants and reactive oxygen species in the human respiratory tract. Sci. Rep. 2016, 6, 32916. [CrossRef]

30. Lodovici, M.; Bigagli, E. Oxidative stress and air pollution exposure. J. Toxicol. 2011, 2011, 487074. [CrossRef]

31. Reinmuth-Selzle, K.; Kampf, C.J.; Lucas, K.; Lang-Yona, N.; Fröhlich-Nowoisky, J.; Shiraiwa, M.; Lakey, P.S.J.; Lai, S.; Liu, F.; Kunert, A.T.; et al. Air Pollution and Climate Change Effects on Allergies in the Anthropocene: Abundance, Interaction, and Modification of Allergens and Adjuvants. Environ. Sci. Technol. 2017, 51, 4119-4141. [CrossRef]

32. Blough, N.V.; Zafiriou, O.C. Reaction of superoxide with nitric oxide to form peroxonitrite in alkaline aqueous solution. Inorg. Chem. 1985, 24, 3502-3504. [CrossRef]

33. Gunaydin, H.; Houk, K.N. Mechanisms of Peroxynitrite-Mediated Nitration of Tyrosine. Chem. Res. Toxicol. 2009, 22, 894-898. [CrossRef]

34. Pfeiffer, S.; Schmidt, K.; Mayer, B. Dityrosine formation outcompetes tyrosine nitration at low steady-state concentrations of peroxynitrite. J. Biol. Chem. 2000, 275, 6346-6352. [CrossRef]

35. Ziegler, K.; Kunert, A.T.; Reinmuth-Selzle, K.; Leifke, A.L.; Widera, D.; Weller, M.G.; Schuppan, D.; Fröhlich-Nowoisky, J.; Lucas, K.; Pöschl, U. Chemical modification of pro-inflammatory proteins by peroxynitrite increases activation of TLR4 and NF-kB: Implications for the health effects of air pollution and oxidative stress. Redox Biol. 2020, 101581. [CrossRef]

36. Bufe, A.; Gehlhar, K.; Schramm, G.; Schlaak, M.; Becker, W.M. Allergenic activity of a major grass pollen allergen is elevated in the presence of nasal secretion. Am. J. Respir. Crit. Care Med. 1998, 157, 1269-1276. [CrossRef]

37. Göbl, C.; Focke-Tejkl, M.; Najafi, N.; Schrank, E.; Madl, T.; Kosol, S.; Madritsch, C.; Dorofeeva, Y.; Flicker, S.; Thalhamer, J.; et al. Flexible IgE epitope-containing domains of Phl p 5 cause high allergenic activity. J. Allergy Clin. Immunol. 2017, 140, 1187-1191. [CrossRef] [PubMed] 
38. Matthiesen, F.; Løwenstein, H. Group V allergens in grass pollens. I. Purification and characterization of the group V allergen from Phleum pratense pollen, Phl p V. Clin. Exp. Allergy 1991, 21, 297-307. [CrossRef] [PubMed]

39. Shiraiwa, M.; Ammann, M.; Koop, T.; Pöschl, U. Gas uptake and chemical aging of semisolid organic aerosol particles. Proc. Natl. Acad. Sci. USA 2011, 108, 11003. [CrossRef] [PubMed]

40. Kampf, C.J.; Liu, F.; Reinmuth-Selzle, K.; Berkemeier, T.; Meusel, H.; Shiraiwa, M.; Pöschl, U. Protein Cross-Linking and Oligomerization through Dityrosine Formation upon Exposure to Ozone. Environ. Sci. Technol. 2015, 49, 10859-10866. [CrossRef]

41. Liu, F.; Lakey, P.S.J.; Berkemeier, T.; Tong, H.; Kunert, A.T.; Meusel, H.; Cheng, Y.; Su, H.; Fröhlich-Nowoisky, J.; Lai, S.; et al. Atmospheric protein chemistry influenced by anthropogenic air pollutants: Nitration and oligomerization upon exposure to ozone and nitrogen dioxide. Faraday Discuss. 2017, 200, 413-427. [CrossRef]

42. Shiraiwa, M.; Sosedova, Y.; Rouvière, A.; Yang, H.; Zhang, Y.; Abbatt, J.P.; Ammann, M.; Pöschl, U. The role of long-lived reactive oxygen intermediates in the reaction of ozone with aerosol particles. Nat. Chem. 2011, 3, 291. [CrossRef]

43. Bedini, A.; Maurino, V.; Minero, C.; Vione, D. Theoretical and experimental evidence of the photonitration pathway of phenol and 4-chlorophenol: A mechanistic study of environmental significance. Photochem. Photobiol. Sci. 2012, 11, 418-424. [CrossRef]

44. Fuentes-Lemus, E.; Silva, E.; Barrias, P.; Aspee, A.; Escobar, E.; Lorentzen, L.G.; Carroll, L.; Leinisch, F.; Davies, M.J.; LopezAlarcon, C. Aggregation of alpha- and beta- caseins induced by peroxyl radicals involves secondary reactions of carbonyl compounds as well as di-tyrosine and di-tryptophan formation. Free Radic. Biol. Med. 2018, 124, 176-188. [CrossRef]

45. Stadtman, E.R. Protein oxidation and aging. Free Radic. Res. 2006, 40, 1250-1258. [CrossRef] [PubMed]

46. Lymar, S.V.; Hurst, J.K. Rapid reaction between peroxonitrite ion and carbon dioxide: Implications for biological activity. J. Am. Chem. Soc. 1995, 117, 8867-8868. [CrossRef]

47. Lymar, S.V.; Jiang, Q.; Hurst, J.K. Mechanism of Carbon Dioxide-Catalyzed Oxidation of Tyrosine by Peroxynitrite. Biochemistry 1996, 35, 7855-7861. [CrossRef] [PubMed]

48. Quijano, C.; Romero, N.; Radi, R. Tyrosine nitration by superoxide and nitric oxide fluxes in biological systems: modeling the impact of superoxide dismutase and nitric oxide diffusion. Free Radic. Biol. Med. 2005, 39, 728-741. [CrossRef] [PubMed]

49. Ke, Z.; Huang, Q. Effect of protein structure and/or conformation on the dityrosine cross-linking induced by haem-hydrogen peroxide. Biochim. Biophys. Acta (BBA) Gen. Subj. 2016, 1860, 2232-2238. [CrossRef]

50. Correia, M.; Neves-Petersen, M.T.; Jeppesen, P.B.; Gregersen, S.; Petersen, S.B. UV-Light Exposure of Insulin: Pharmaceutical Implications upon Covalent Insulin Dityrosine Dimerization and Disulphide Bond Photolysis. PLoS ONE 2012, 7, e50733. [CrossRef]

51. Lehrer, S.S.; Fasman, G.D. Ultraviolet Irradiation Effects in Poly-L-tyrosine and Model Compounds. Identification of Bityrosine as a Photoproduct*. Biochemistry 1967, 6, 757-767. [CrossRef]

52. Malencik, D.A.; Anderson, S.R. Fluorometric characterization of dityrosine: Complex formation with boric acid and borate ion. Biochem. Biophys. Res. Commun. 1991, 178, 60-67. [CrossRef]

53. Liu, F.; Reinmuth-Selzle, K.; Lai, S.; Weller, M.G.; Pöschl, U.; Kampf, C.J. Simultaneous determination of nitrated and oligomerized proteins by size exclusion high-performance liquid chromatography coupled to photodiode array detection. J. Chromatogr. A 2017, 1495, 76-82. [CrossRef]

54. Selzle, K.; Ackaert, C.; Kampf, C.J.; Kunert, A.T.; Duschl, A.; Oostingh, G.J.; Pöschl, U. Determination of nitration degrees for the birch pollen allergen Bet v 1. Anal. Bioanal. Chem. 2013, 405, 8945-8949. [CrossRef]

55. Yang, H.; Zhang, Y.; Pöschl, U. Quantification of nitrotyrosine in nitrated proteins. Anal. Bioanal. Chem. 2010, 397, 879-886. [CrossRef] [PubMed]

56. Zhang, Y.; Yang, H.; Pöschl, U. Analysis of nitrated proteins and tryptic peptides by HPLC-chip-MS/MS: Site-specific quantification, nitration degree, and reactivity of tyrosine residues. Anal. Bioanal. Chem. 2011, 399, 459-471. [CrossRef] [PubMed]

57. Sander, R. Compilation of Henry's law constants (version 4.0) for water as solvent. Atmos. Chem. Phys. 2015, 15, 4399-4981. [CrossRef]

58. Umweltbundesamt. Trend der Ozon-Jahresmittelwerte. Available online: https://www.umweltbundesamt.de/sites/default/ files/medien/384/bilder/dateien/7_abb_trend-ozon-jmw_2020-10-09.xlsx (accessed on 8 March 2021).

59. Umweltbundesamt. Zahl der Tage mit Überschreitung des Ozon-Zielwertes $\left(120 \mu \mathrm{g} / \mathrm{m}^{3}\right)$ Zum Schutz der Menschlichen Gesundheit. Available online: https://www.umweltbundesamt.de/sites/default/files/medien/384/bilder/dateien/5_abb_ ozon-ueberschreitung-120_2020-10-09.xlsx (accessed on 8 March 2021).

60. Umweltbundesamt. Stickstoffdioxid $\left(\mathrm{NO}_{2}\right)$ im Jahr 2019. Available online: https://www.umweltbundesamt.de/sites/default/ files/medien/2546/dokumente/no2_2019.xlsx (accessed on 12 March 2021).

61. Kouti, L.; Noroozian, M.; Akhondzadeh, S.; Abdollahi, M.; Javadi, M.R.; Faramarzi, M.A.; Mousavi, S.; Ghaeli, P. Nitric oxide and peroxynitrite serum levels in Parkinson's disease: Correlation of oxidative stress and the severity of the disease. Eur. Rev. Med. Pharmacol. Sci. 2013, 17, 964-970. 